\title{
YIELD AND HERB QUALITY OF THYME (Thymus vulgaris L.) DEPENDING ON HARVEST TIME
}

\author{
Beata KRÓL ${ }^{*}$, Anna KIEŁTYKA-DADASIEWICZ ${ }^{2}$ \\ ${ }^{1}$ University of Life Sciences in Lublin, Department of Industrial and Medicinal Plants, POLAND, \\ ${ }^{2}$ State Higher Vocational School in Krosno, POLAND \\ *Corresponding author: beata.krol@up.lublin.pl
}

Received: 02.04.2014

\begin{abstract}
Thyme (Thymus vulgaris $\mathbf{L}$ ) is a medical and aromatic plant intensively used in pharmaceutical, food, and cosmetic industries. Our investigations carried out in 2010-2011 were focused on effect of harvest time on yield and herb quality of two thyme cultivars ('Sloneczko' and 'Deutscher Winter'). Plants were harvested in the first year of cultivation in three periods: 140, 160, and 180 days after sowing (i.e. in the third decade of August, second decade of September and first decade of October). The study showed that harvesting time had a significant effect on the yield and quality of thyme. The delayed harvesting resulted in increased plant height and their mass but decreased quality of herb (lesser quantity of essential oil and thymol). The optimal time of harvest appeared to be $\mathbf{1 6 0}$ days after sowing (i.e. in the second decade of September. Harvest in this time ensured fairly good yield of herb and high its quality. The weather conditions prevailing during the vegetation period had a substantial effect on the yield and quality of herb. The 'Deutscher Winter' cultivar produced higher yields in favourable weather conditions, whereas the 'Sloneczko' cultivar exhibited a more stable yield in adverse atmospheric conditions.
\end{abstract}

Key words: cultivar, essential oil content, thymol, Thymus vulgaris

\section{INTRODUCTION}

Thyme (Thymus vulgaris L.) is a perennial plant belonging to the Lamiaceae family. It is native to Europe and the Mediterranean basin and adaptable to a wide range of environmental conditions (Stahl-Biskup and Sáez, 2002). Thyme is an aromatic medicinal plant of increasing economic importance in Europe, Asia, North Africa and North America. Essential oil of thyme has been reported to be one of top 10 of essential oils (Maghdi and Maki, 2003)

The pharmacological properties of the plant and of its different extracts, in particular the essential oils, has been thoroughly studied and afforded the many industrial mainly as food and cosmetic additive (Sacchetti et al., 2005) and medical applications (Maghdi and Maki, 2003). The oil was reported to have antimicrobial (bacteria and fungi) (Cetin et al., 2011), expectorant (Büechi et al., 2005) activities, most of which are mediated by thymol and carvacrol. Antispasmodic (Begrow et al., 2010) as well as antioxidant (Haraguchi et al., 1996) activities were also reported for the alcoholic extract of the plant.

Thyme is cultivated in many regions of world and is one of the most important medicinal plant in Europe. Thyme plantations usually survive 2 or 3 year, but in some regions, the plants may freeze during cold winters. Therefore in countries, where the winters are severe
(Scandinavian countries, Eastern Europe and Canada) thyme is treated as a one year culture (Dambrauskiene et al., 1999; Letchamo et al., 1999; Galambosi et al., 2002).

The yield of herb of thyme can be influenced by environmental factors, as well as by agricultural practice (Stahl-Biskup and Sáez, 2002). Harvesting time is one of the important factors determining the quantitative and qualitative characteristics of thyme (Badi et al., 2004)

The essential oil content and its chemical composition are the most important characteristics of aromatic herbs. Content of essential oil in dry herb of thyme ranges from $0.3 \%$ (Ozguven and Tansi, 1998) to $4.0 \%$ (Carlen et al., 2010). The content of the essential oil depends from several factors, the most important being genetic characteristics, stage of development (Christensen and Grevsen, 2006; Mewes at al., 2008) environmental conditions (Raal et al., 2005; Alizadeh et al., 2011). Agronomic factors (Kołodziej, 2009; Król, 2009) as well as drying and storage conditions (Calin-Sanchez et al., 2013) exerts an influence on the essential oils content too. There are however scarce information on the effect time of harvest on the chemical composition of essential oil.

The aim of this study was to analyze the impact of time of the harvest on the yield and quality of herb two cultivars of thyme utilized as a one year plantation 


\section{MATERIALS AND METHODS}

The study was carried out at the Experimental Farm of the University of Life Sciences in Lublin ( $51^{\circ} 14^{\prime} 53^{\prime \prime} \mathrm{N}$, $\left.22^{\circ} 34^{\prime} 13^{\prime \prime} \mathrm{E}\right)$, Poland, during the 2010 and 2011 growing seasons. The experiment was conducted on brown podzolic soil of loess origin, neutral in reaction $\left(\mathrm{pH}_{\mathrm{KCl}}\right.$ 7.1 ), characterized by high content of phosphorus ( 85 $\mathrm{mg} \cdot \mathrm{P} \mathrm{kg}^{-1}$ ) and average potassium (166 $\mathrm{mg} \mathrm{K} \cdot \mathrm{kg}^{-1}$ ) and magnesium (65 $\left.\mathrm{mg} \mathrm{Mg} \cdot \mathrm{kg}^{-1}\right)$ contents.

The study comprised two cultivars of thyme ('Słoneczko' and 'Deutscher Winter') and consisted of three harvest times: H1 - 140 days after sowing (DAS) i.e. in the third decade of August; H2 - 160 DAS - i.e. in the second decade of September; and H3 - 180 DAS - i.e. in the first decade of October. The 'Słoneczko' cultivar seeds were supplied by the Institute of Natural Fibres and Medicinal Plants, Poland and the 'Deutscher Winter' cultivar by Bingenheimer Saatgut AG, Germany. The study was conducted in a randomized block design with four replications. Each experimental plot was $4 \mathrm{~m}$ long and $2.5 \mathrm{~m}$ wide $\left(10 \mathrm{~m}^{2}\right)$. Seeds were sown directly into the ground in the first decade of April in rows spaced $30 \mathrm{~cm}$ (sowing rate $5 \mathrm{~kg}$ seeds $\mathrm{ha}^{-1}$ ). Mineral fertilizers were applied in the amount of $\mathrm{N}-60 ; \mathrm{P}-22 ; \mathrm{K}-100 \mathrm{~kg}$ per ha

(phosphorus and potassium were applied as triple superphosphate and potassium chloride before sowing the seeds). Nitrogen fertilization was applied (in two doses half before sowing and half after plant emergence) as ammonium nitrate. Manual weed control and soil loosening in interrow spaces was performed during the growth of plants.

Before harvest, plant height was determined (20 plants measured from each object). After harvest, the herb was weighed and dried (in a drying house at $35^{\circ} \mathrm{C}$ ) and air-dry mass was determined. Next, the herb was rubbed on sieves (mesh diameter 5mm) and thus dry leaves yield was obtained.

The essential oil was extracted from air-dried leaves $(30 \mathrm{~g})$ in a glass Clevenger-type distillation apparatus following European Pharmacopoeia (2004) and subjecting the material to hydrodistillation for $3 \mathrm{~h}$. The assays were conducted in triplicate. The extracted essential oil was stored in a dark glass container at a temperature of $-10^{\circ} \mathrm{C}$ until the time of chromatographic separation. The quantitative and qualitative determination of the essential oil components was made using a gas chromatograph (Varian 4000 GC/MS/MS) equipped with a FID detector and fused silica capillary column $(25 \mathrm{~m} \times 0.2 \mathrm{~mm})$. The carrier gas was helium with the splitting ratio of 1:1000 and capillary flow rate of $0.5 \mathrm{ml} \mathrm{min}{ }^{-1}$. A temperature of $50^{\circ} \mathrm{C}$ was applied for $1 \mathrm{~min}$, and then the temperature was incremented to $250^{\circ} \mathrm{C}$ at a rate of $4^{\circ} \mathrm{C} \mathrm{min}^{-1} ; 250^{\circ} \mathrm{C}$ was applied for $10 \mathrm{~min}$. The qualitative analysis was carried out on the basis of MS spectra, which were compared with the spectra in the NIST Mass Spectral Library (NIST 2002) and with data available in the literature (Joulain and König, 1998; Adams 2001). The identity of the compounds was confirmed by their retention indices, taken from the literature (Joulain and König, 1998; Adams 2001).

The predicted production yields of thyme oils, in litres per hectare, were calculated from the dry leaves yield and the oil content. The numerical results of the experiment were statistically elaborated by the analysis of variance (ANOVA) for three factors - harvest time $\mathrm{H}$ (3), cultivars C (2) and years Y (2). The least significant difference test was used to compare differences in means among treatments at the 0.05 probability level.

The basic climatic factors during thyme vegetation are presented in Table 1 . In order to determine the variability of meteorological factors and assess their effect on the yield and quality of the plant, the Sielianinov hydrothermal coefficient $(\mathrm{k})$ was calculated based on the equation: $\mathrm{k}=\mathrm{P} / 0.1 \sum \mathrm{t}$

$\mathrm{P}$ - total rainfall in the given period $(\mathrm{mm})$

$\Sigma \mathrm{t}$ - total of average daily air temperatures from that period $\left({ }^{\circ} \mathrm{C}\right)$ (Skowera and Puła, 2004).

According to the classification presented by Skowera and Puła (2004), there are distinguished the following conditions: extremely dry $(\mathrm{k} \leq 0.4)$, very dry $(\mathrm{k} \leq 0.7)$, dry $(\mathrm{k} \leq 1.0)$, rather dry $(\mathrm{k} \leq 1.3)$, optimal $(\mathrm{k} \leq 1.6)$, rather wet $(\mathrm{k} \leq 2.0)$, wet $(\mathrm{k} \leq 2.5)$, very wet $(\mathrm{k} \leq 3.0)$, and extremely wet $(\mathrm{k}>3.0)$.

Thermal conditions in both years of the field experiment were favourable for thyme; the average air temperature in the vegetation season was markedly higher if compared with that in the long-term period. Moisture conditions were also more favourable than in the longterm period. In terms of precipitation, 2010 was more advantageous, not only because of greater amounts but also more uniform distribution of rainfall. In 2011, symptoms of drought (in May) and severe drought (in August and September) occurred as a result of irregular rainfall. 
Table 1. Rainfall, air temperature and hydrothermal coefficient during vegetation of thyme in 2010 and 2011 in comparison with multi-year period (1980-2009)

\begin{tabular}{|c|c|c|c|c|c|c|c|c|}
\hline \multirow[b]{2}{*}{ Year } & \multicolumn{8}{|c|}{ Month } \\
\hline & April & May & June & July & August & September & October & $\begin{array}{l}\text { Mean or } \\
\text { Total }\end{array}$ \\
\hline \multicolumn{9}{|c|}{ Average temperature of air $\left({ }^{\circ} \mathrm{C}\right)$} \\
\hline 2010 & 9.4 & 14.0 & 17.8 & 21.2 & 19.5 & 12.3 & 5.6 & 14.2 \\
\hline \multirow{2}{*}{$\begin{array}{l}2011 \\
\text { mean for } \\
\text { long term }\end{array}$} & 10.8 & 14.3 & 18.5 & 18.1 & 19.0 & 15.5 & 8.0 & 14.8 \\
\hline & 8.4 & 14.1 & 16.8 & 18.5 & 18.1 & 13.5 & 8.4 & 13.9 \\
\hline \multicolumn{9}{|c|}{ Monthly of rainfall (mm) } \\
\hline \multirow{3}{*}{$\begin{array}{l}2010 \\
2011 \\
\text { mean for } \\
\text { long term }\end{array}$} & 34.1 & 108.4 & 44.8 & 125.7 & 106.1 & 88.9 & 9.2 & 517.2 \\
\hline & 44.9 & 30.7 & 55.5 & 282.9 & 17.8 & 5.9 & 23.8 & 461.5 \\
\hline & 41.3 & 63.2 & 70.6 & 83.1 & 68.4 & 53.5 & 24.1 & 404.2 \\
\hline \multicolumn{9}{|c|}{ Sielianinov's hydrothermal coefficient } \\
\hline 2010 & 1.21 & 2.58 & 0.83 & 1.91 & 1.75 & 2.41 & 0.54 & 1.60 \\
\hline 2011 & 1.38 & 0.69 & 1.00 & 5.04 & 0.30 & 0.13 & 0.95 & 1.35 \\
\hline $\begin{array}{l}\text { mean for } \\
\text { long term }\end{array}$ & 1.64 & 1.45 & 1.40 & 1.44 & 1.22 & 1.32 & 0.92 & 1.34 \\
\hline
\end{tabular}

Source: Laboratory of Agrometeorology, University of Life Sciences in Lublin, Poland

\section{RESULTS AND DISCUSSION}

The height of plants oscillated between 23.4 and 32.8 $\mathrm{cm}$ and markedly depended on both: harvesting time and weather conditions during vegetation (Table 2). The plants were higher in 2010, when the rainfall was greater and more uniformly distributed than in 2011. (Table 1,2). At the consecutive harvests the height of plants increased (the significant differences however were only between the first and third harvest). The height of thyme plants varies to a great extent and depends on the genotype (Mewes at al., 2008), environmental conditions (Galambosi et al., 2002) and cultivation practice (Badi et al., 2004) and oscillates between 10 and $50 \mathrm{~cm}$.

Table 2. The influence of harvest time on height of plants of thyme $(\mathrm{cm})$

\begin{tabular}{lccccc}
\hline \multirow{2}{*}{ Cultivar } & Year & \multicolumn{3}{c}{ Harvest time } & \multirow{2}{*}{ Mean } \\
\cline { 3 - 5 } & & H1* & H2 & H3 & 30.0 \\
'Słoneczko' & 2010 & 27.8 & 30.9 & 31.4 & 26.9 \\
& 2011 & 23.4 & 25.1 & 26.2 & 27.5 \\
\cline { 2 - 5 } & Mean & 25.6 & 28.0 & 28.8 & 30.8 \\
'Deutscher Winter' & 2010 & 28.2 & 31.4 & 32.8 & 26.4 \\
\hline Mean for harvest time & 2011 & 25.6 & 26.4 & 27.2 & 28.6 \\
\cline { 2 - 5 } & Mean & 26.9 & 28.9 & 30.0 & 28.1 \\
\hline
\end{tabular}

$\mathrm{LSD}_{0.05}$ harvest time $(\mathrm{H})$ - 2.53; cultivar $(\mathrm{C})$ - ns.; years (Y) - 4.25; H x C - ns.; C x Y - 3.71; H x Y - 3.34

ns. - no significant differences

${ }^{*} \mathrm{H} 1$ - 140 days after sowing

$\mathrm{H} 2$ - 160 days after sowing

H3 - 180 days after sowing

The herb yield depended significantly on the factors studied (Table 3). In both cultivars, the highest yields of fresh and air-dry herb were achieved from plants harvested in the first decade of October (i.e. 180 DAS), while the lowest - during the first harvest (140 DAS). No significant differences were found in the fresh and air dry herb yields between the cultivars, however, the 'Słoneczko' yields were more stable in adverse weather conditions in 2011 year when there were symptoms of drought (Table 3). Chauhan et al. (2011) in diverse climatical conditions the highest yields of fresh and dry mass of herb obtained when thyme was harvested 115 days after sowing. The latest harvesting (180 DAS) caused decreased fresh and dry herb weight, which resulted from stem drying and defoliation. Rey (1991) considers harvest time of thyme as an important factor affecting yields and their quality. He asserts, that optimal time may differ markedly between particular regions. 
Table 3. The influence of harvest time of thyme on yield of fresh and air dry herb and ratio fresh to air dry herb

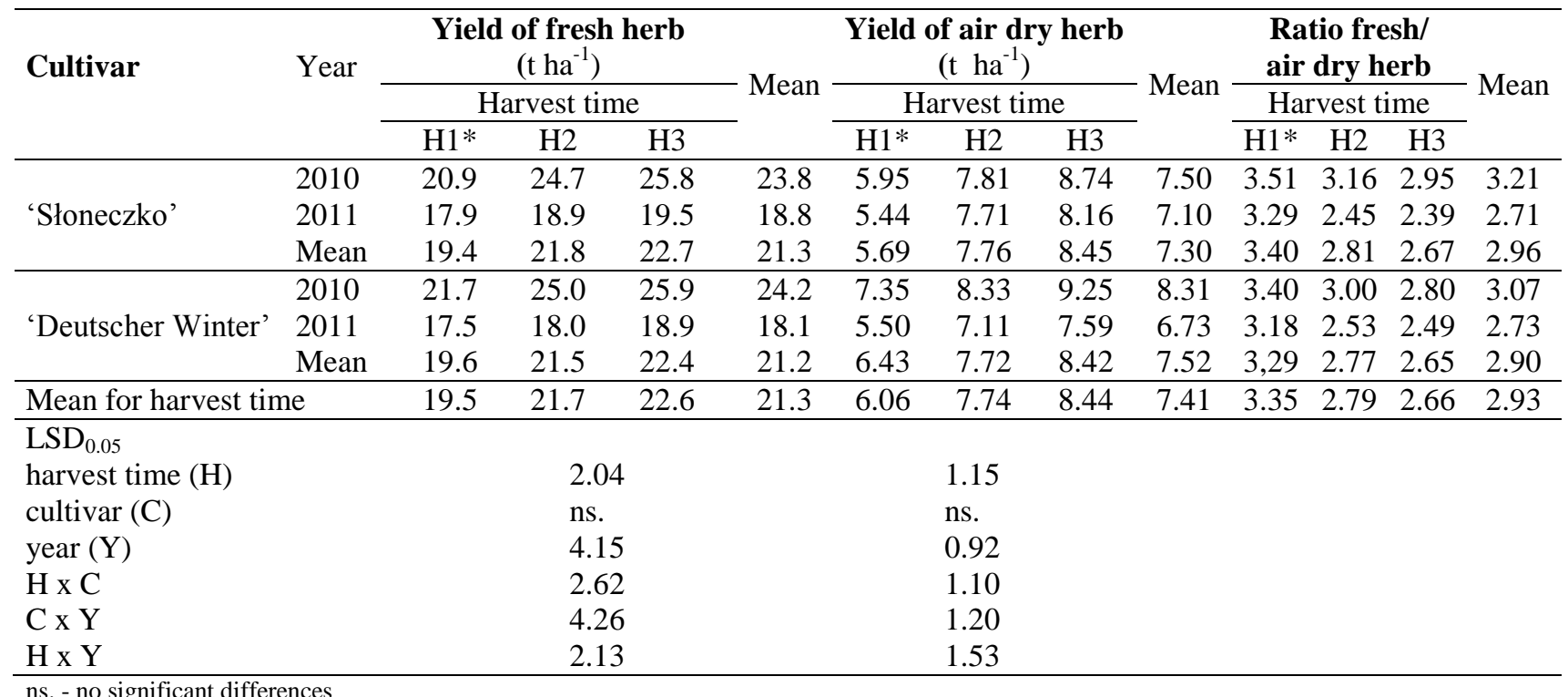

ns. - no significant differences

${ }^{*}$ See table 2

The ratio of the fresh to dry herb weight in our experiment ranged from 2.39 to 3.51 (Table 3). A high value of this trait is disadvantageous, as this involves higher costs of drying. The delay in harvesting thyme decreased water content in the herb, which resulted in a decline in the proportion between the fresh and air-dry weight of the herb (Table 3). According to literature data, the ratio of fresh to dry herb weight in thyme grown in Poland is 2.4 - 3.5 (Kołodziej 2009; Król, 2009). Similar value of this feature $(2.6-3.7)$ was reported in experiments conducted in diverse climatic conditions (Badi et al., 2004).

In our experiment, the dry leaves yields ranged between 2.23 and $4.08 \mathrm{t} \cdot \mathrm{ha}^{-1}$, and corresponded with results obtained by other authors in Poland (Table 4) (Kołodziej, 2009; Król, 2009). Similar results were obtained in Finland whereas in Canada thyme yields were lower and did not exceed $1.5 \mathrm{t} \cdot \mathrm{ha}^{-1}$ (Letchamo et al., 1999). Stahl-Biskup and Sáez (2002) report that yields of thyme in the first year of vegetation amount from 2 to 2.5 $t \cdot h a^{-1}$, of dry plant material. Investigations conducted by Dudaš and Böhme (2004) showed that the 'Deutscher Winter' gave higher yield than the 'Słoneczko', which in turn was characterised by a better proportion of leaves. In our experiment, there were no differences in the mean yields of dry leaves between these cultivars, but an interaction between the cultivars and years was reported. 'Deutscher Winter' produced higher yields in favourable weather conditions (2010), whereas in unfavourable weather (2011), yields were significantly reduced (by $32 \%$ ). Also Galambosi et al. (2002) reported strong susceptibility of this cultivar to adverse atmospheric conditions (decrease of yields by 15-35\%).

Table 4. Yield of dry leaves and contribution of leaves in herb of thyme

\begin{tabular}{|c|c|c|c|c|c|c|c|c|c|}
\hline \multirow{3}{*}{ Cultivar } & \multirow[t]{3}{*}{ Year } & \multirow{2}{*}{\multicolumn{3}{|c|}{$\begin{array}{c}\begin{array}{c}\text { Yield of dry leaves } \\
\left(\mathrm{t} \mathrm{ha}^{-1}\right)\end{array} \\
\text { Harvest time }\end{array}$}} & \multirow{3}{*}{ Mean } & \multirow{2}{*}{\multicolumn{3}{|c|}{$\begin{array}{c}\begin{array}{c}\text { Contribution of leaves } \\
(\%)\end{array} \\
\text { Harvest time }\end{array}$}} & \multirow{3}{*}{ Mean } \\
\hline & & & & & & & & & \\
\hline & & $\mathrm{H} 1 *$ & $\mathrm{H} 2$ & $\mathrm{H} 3$ & & $\mathrm{H} 1 *$ & $\mathrm{H} 2$ & $\mathrm{H} 3$ & \\
\hline \multirow{3}{*}{ 'Słoneczko' } & 2010 & 2.71 & 3.57 & 3.83 & 3.37 & 47.0 & 46.5 & 44.6 & 46.0 \\
\hline & 2011 & 2.54 & 3.02 & 3.27 & 2.94 & 41.5 & 40.7 & 38.9 & 40.4 \\
\hline & Mean & 2.63 & 3.29 & 3.45 & 3.12 & 44.3 & 43.6 & 41.8 & 43.2 \\
\hline \multirow{3}{*}{$\begin{array}{l}\text { 'Deutscher } \\
\text { Winter' }\end{array}$} & 2010 & 3.42 & 3.83 & 4.08 & 3.78 & 45.2 & 44.7 & 42.8 & 44.2 \\
\hline & 2011 & 2.23 & 2.73 & 2.79 & 2.58 & 39.1 & 37.2 & 35.5 & 37.3 \\
\hline & Mean & 2.83 & 3.28 & 3.43 & 3.18 & 42.2 & 40.9 & 39.2 & 40.8 \\
\hline \multicolumn{2}{|c|}{ Mean for harvest time } & 2.73 & 3.29 & 3.44 & 3.15 & 43.2 & 42.3 & 40.5 & 41.9 \\
\hline \multicolumn{10}{|c|}{$\begin{array}{l}\mathrm{LSD}_{0.05} \\
\text { harvest time }(\mathrm{H})-0.41 \text {; cultivar }(\mathrm{C})-\mathrm{n} . \mathrm{s} ; \text { year }(\mathrm{Y})-0.73 \\
\mathrm{H} \text { x C }-0.70 ; \mathrm{C} \text { x Y }-0.84 ; \mathrm{H} \text { x Y }-0.65\end{array}$} \\
\hline
\end{tabular}


Both cultivars produced the lowest yield of dry leaves in the objects with the earliest harvest (140 DAS), delaying harvest resulted in significant increase of yield (Table 4).

An important indication of the quality herb of thyme is the percentage of leaves, as the essential oil is accumulated in oil glandules present in these organs but scarce in the stems (they are discarded in the final stage of raw material preparation) (Sharafzadeh et al., 2010). Słoneczko' cultivar is characterised by the highest amounts of leaves among the European varieties of thyme (Dudaš and Böhme, 2004). Similarly, in our research the 'Słoneczko' cultivar contained greater amounts of leaves (43.2\% versus $40.8 \%$ in the 'Deutscher Winter' cultivar) (Table 4). The share of leaves in air-dry weight was also related to weather conditions and time of harvest. In both cultivars, the highest share of leaves was noted in herb from the first harvest (140 DAS) and the lowest - at the last harvest (180 DAS- Table 4). This was probably caused by defoliation and lignification of stems. However in experiment of Rey (1991) in different climatical conditions the delay in harvesting thyme increased share of leaves.
In our study, the content of essential oil in the dry leaves ranged from 2.23 to $3.61 \%$ (Table 5) and was comparable with results of Galambosi et al. (2002), Zawiślak (2007), Marzec et al. (2010) but higher than stated by Badi et al. (2004), Alizadeh et al. (2011) and Christensen and Grevsen (2006). The content of essential oil in thyme plants can be markedly affected by environmental conditions, time of harvest and other agronomical factors (Stahl-Biskup and Sáez, 2002; Raal et al., 2005). In our study, the content of essential oil in the dry leaves of both cultivars was largely determined by the harvest date and weather conditions during the vegetation season (both cultivars responded similarly - Table 5). The herb was harvested at the first date contained the greatest quantity of essential oil (mean $3.44 \%$ ) whereas the smallest - at the third date $(2.67 \%)$. The differences between the first and second harvest were negligible while between second and third - considerable. Decreasing content of essential oil accompanying delayed thyme harvest was reported by Badi et al. (2004) and Rey (1991). Also Christensen and Grevsen (2006), obtained more essential oil in thyme herb harvested in September than in October. Galambosi et al. (2002) however report that shorter growing season affects first at all biomass production, and has only slight influence on essential oil content and composition.

Table 5. The effect of harvest time of thyme on the content and yield of essential oil; percent of thymol in oil

\begin{tabular}{|c|c|c|c|c|c|c|c|c|c|c|c|c|c|}
\hline \multirow[t]{3}{*}{ Cultivar } & \multirow[t]{3}{*}{ Year } & \multirow{2}{*}{\multicolumn{3}{|c|}{$\begin{array}{c}\begin{array}{c}\text { Essential oil content } \\
(\%)\end{array} \\
\text { Harvest time } \\
\end{array}$}} & \multirow{3}{*}{ Mean } & \multirow{2}{*}{\multicolumn{3}{|c|}{$\begin{array}{c}\begin{array}{c}\text { Yield of essential oil } \\
\left(\mathrm{kg} \cdot \mathrm{ha}^{-1}\right)\end{array} \\
\text { Harvest time } \\
\end{array}$}} & \multirow{3}{*}{ Mean } & \multirow{2}{*}{\multicolumn{3}{|c|}{$\begin{array}{c}\text { Thymol } \\
(\%)\end{array}$}} & \multirow{3}{*}{ Mean } \\
\hline & & & & & & & & & & & & & \\
\hline & & $\mathrm{H} 1 *$ & $\mathrm{H} 2$ & H3 & & H1* & $\mathrm{H} 2$ & $\mathrm{H} 3$ & & H1* & $\mathrm{H} 2$ & $\mathrm{H} 3$ & \\
\hline \multirow{3}{*}{ 'Słoneczko' } & 2010 & 3.48 & 3.35 & 2.87 & 3.23 & 94 & 120 & 110 & 108 & 59.2 & 57.5 & 55.1 & 57.3 \\
\hline & 2011 & 3.32 & 3.05 & 2.59 & 2.99 & 74 & 92 & 80 & 82 & 55.8 & 54.3 & 52.7 & 54.3 \\
\hline & Mean & 3.40 & 3.20 & 2.73 & 3.11 & 84 & 105 & 95 & 95 & 57.5 & 55.9 & 53.9 & 55.8 \\
\hline \multirow{3}{*}{$\begin{array}{l}\text { 'Deutscher } \\
\text { Winter' }\end{array}$} & 2010 & 3.61 & 3.43 & 2.98 & 3.34 & 123 & 131 & 122 & 125 & 54.1 & 52.7 & 50.3 & 52.4 \\
\hline & 2011 & 3.35 & 2.64 & 2.23 & 2.74 & 75 & 72 & 62 & 70 & 53.2 & 52.1 & 49.9 & 51.7 \\
\hline & Mean & 3.48 & 3.04 & 2.61 & 3.06 & 99 & 101 & 92 & 98 & 53.7 & 52.4 & 50.1 & 51.9 \\
\hline \multicolumn{2}{|c|}{ Mean for harvest time } & 3.44 & 3.12 & 2.67 & 3.08 & 92 & 103 & 94 & 96 & 55.6 & 54.2 & 52.0 & 53.9 \\
\hline \multicolumn{14}{|l|}{$\mathrm{LSD}_{0.05}$} \\
\hline \multirow{2}{*}{\multicolumn{2}{|c|}{$\begin{array}{l}\text { harvest time }(\mathrm{H}) \\
\text { cultivar }(\mathrm{C})\end{array}$}} & \multicolumn{4}{|c|}{4.42} & \multicolumn{3}{|c|}{8.2} & & \multicolumn{4}{|c|}{3.1} \\
\hline & & \multicolumn{3}{|c|}{ ns. } & & \multicolumn{3}{|c|}{ n.s } & & \multicolumn{4}{|c|}{3.7} \\
\hline year $(Y)$ & & \multicolumn{3}{|c|}{4.12} & & \multicolumn{3}{|c|}{25.7} & & \multicolumn{4}{|c|}{ ns. } \\
\hline $\mathrm{H} \times \mathrm{C}$ & & \multicolumn{3}{|c|}{3.92} & & \multicolumn{3}{|c|}{13.1} & & \multicolumn{4}{|c|}{3.5} \\
\hline $\mathrm{C} \times \mathrm{Y}$ & & \multicolumn{3}{|c|}{4.65} & & \multicolumn{3}{|c|}{28.3} & & \multicolumn{4}{|c|}{ ns. } \\
\hline $\mathrm{H} \times \mathrm{Y}$ & & \multicolumn{3}{|c|}{3.73} & & \multicolumn{3}{|c|}{15.5} & & \multicolumn{4}{|c|}{3.9} \\
\hline
\end{tabular}

${ }^{*}$ See table 2

ns - no significant differences

In our experiment the mean content of essential oil in both cultivars did not differ markedly (Table 5). In study carried out by Dudaš and Böhme (2004) where there were compared several European cultivars, herb of 'Deutscher Winter' contained more essential oil in comparison with 'Słoneczko'. Seidler-Łożykowska (2007) reported that atmospheric conditions prevailing during the growing season were an important factor determining essential oil content in thyme. In our study, both the herb yield and oil content were higher in 2010 , which was characterised by higher precipitation rates and lower temperatures during the growing season, than those in 2011 (Table 4, 5). Berbeć and Kołodziej (2007) found that appropriate water supply ensured high yields but also contributed to reduction of the quantity of active compounds in herb, in our experiment however this opinion was not confirmed.

In our experiment, the oil yield (a resultant of dry leaf yield and essential oil content) was the highest (irrespective of the cultivar) in objects where the plants were harvested 160 days after seed sowing (Table 5). The 
mean essential oil yields (regardless of the years and harvesting periods) in both cultivars did not differ significantly. Comparison of the essential oil yields in relation to the year of study revealed greater variation in the 'Deutscher Winter' cultivar, which strongly reacted to the water deficiency in August and September 2011 by a substantial decline in the essential oil yield. In turn, at the favourable precipitation distribution in 2010, this cultivar gave higher yields of essential oil than the 'Słoneczko' cultivar (Table 5).

Content of thymol in essential oil is considered to be one of important factors of thyme quality (Stahl-Biskup and Sáez, 2002). In our study this content ranged from $49.9 \%$ to $59.2 \%$ and was comparable with that determined by Zawiślak (2007), Galambosi et al. 2002, and Marzec et al. (2010). Asllani and Toska (2003) found it at the lower level (23.1\%-50.1\%) in Albanian thyme, Horváth et al. (2006) in herbs from Hungary $(40,5 \%)$ and Badi et al. (2004) in essential oil from thyme grown in Iran (36\% $45 \%$ ). The chemical composition of thyme's essential oil depends upon several factors, such as environment of growing (Galambosi et al. 2002), development stage (Hudaib et al., 2002) and chemotypes (Thompson et al., 2003). In our study, the content of thymol in the essential oil was dependent on the harvest date and cultivars (Table 5). The highest level of thymol was recorded in herb harvested in the third decade of August, (i.e. 140 days after sowing), and succeeding harvests brought about decrease its content. The similar dependence observed Chauhan et al. (2011), and Hudaib et al. (2002). Senatore (1996) who investigated the essential oil of a wild Italian thyme, Thymus pulegioides L., the highest content of thymol found in herb gathered in May (39.1\%) and much smaller in September $(20.8 \%)$. This does not correspond however with the experiment of Christensen and Grevsen (2006) who found more thymol in herb cultivated thyme harvested in October in comparison with that harvested in September. In our experiment markedly more thymol conatined herb of 'Słoneczko' cultivar in comparison with 'Deuscher Winter' (Table 5). Also Dudaš and Böhme (2004), reported that 'Słoneczko' characterized the highest amounts of thymol in essential oil among compared cultivars.

\section{CONCLUSIONS}

Examined in the experiment harvest dates of the thyme (140, 160, and 180 days after sowing) had a significant effect on the herb yield and its quality. Along with delaying harvest, yield increased while quality of herb decreased. The highest yield of herb was recorded at latest date of harvest (180 days after sowing), the herb however characterized low quality, contained smaller quantity of essential oil and lesser amount of valuable thymol. The optimal harvest time of both cultivars compared ('Słoneczko' and 'Deutscher Winter') proved to be 160 days after sowing (mid of September), when fairly good yields were accompanied by reasonable quality of herb. The weather conditions during the vegetation period had a significant effect on the herb yield and a minor impact on the its quality. Higher yields of herb was recorded in 2010 year which characterized abound and uniformly distributed rainfall.

\section{LITERATURE CITED}

Adams, R.P. 2001. Identification of essential oil compounds by gas chromatography/quadrupole mass spectroscopy. Allured, Carol Stream, IL, USA.

Alizadeh, A., O. Alizadeh, S. Sharafzadeh, S. Mansoori. 2011. Effect of different ecological environments on growth and active substances of garden thyme. Adv. Envir. Bio. 5: 780783.

Asllani, U., V. Toska. 2003. Chemical composition of Albanian thyme oil (Thymus vulgaris L.). J. Essent. Oil Res. 15(3): 165-167.

Badi, H.N., D. Yazdani, S.M Ali, N. Fatemeh. 2004. Effects of spacing and harvesting time on herbage yield and quality/quantity of oil in thyme, Thymus vulgaris L. Ind. Crops Prod. 19(3): 231-236.

Begrow, F., J. Engelbertz, B. Feistel, R. Lehnfeld, K. Bauer, E. J. Verspohl. 2010. Impact of thymol in thyme extracts on their antispasmodic action and ciliary clearance. Planta Med. 76(04): 311-318.

Berbeć, S., B. Kołodziej. 2007. The effects of herbs irrigation. Herba Pol. 53(3): 141-145.

Büechi, S., R. Vögelin, M.M. Von Eiff, M. Ramos, J. Melzer. 2005. Open trial to assess aspects of safety and efficacy of a combined herbal cough syrup with ivy and thyme. Res. Complement. Med. 12(6): 328-332.

Calin-Sanchez, A., A. Figiel, K. Lech, A. Szumny, A.A. Carbonell-Barrachina. 2013. Effects of drying methods on the composition of Thyme (Thymus vulgaris L.) essential oil. Drying Technol. 31(2): 224-235.

Carlen, C., M. Schaller, C.A. Carron, J.F. Vouillamoz, C.A. Baroffio. 2010. The new Thymus vulgaris L. hybrid cultivar (Varico 3) compared to five established cultivars from Germany, France and Switzerland. Acta Hort. 860: 161-166.

Cetin, B., S. Cakmakci, R.Cakmakci. 2011. The investigation of antimicrobial activity of thyme and oregano essential oils. Turk. J. Agric. For., 35: 145-154.

Chauhan, N.K., S. Singh, H. Lohani, Z.S. Heider. 2011. Effect of different harvesting time on growth, yield and quality of thyme under the agro-climatic conditions of Doon Valley, Uttarakhand. J. Chem. Pharm. Res. 3 (6): 982-986.

Christensen, L.P., K. Grevsen. 2006. Effect of development stage at harvest on the composition and yield of essential oils from thyme and oregano. Dev. Food Sci. 43: 261-264.

Dudaš, S., M. Böhme. 2004. Characteristics of thyme varieties in comparison. Gartenbauwissenschaftliche Tagung, 39.

Dambrauskiene, E., P. Viskelis. R. Venskutonis. 1999. Effect of nitrogen fertilizers on the yield of first year thyme and its quality. Scientific Works, 18: 107-112.

European Pharmacopoeia. $4^{\text {th }}$ ed. Version 4.08. 2004, Strasbourg: EDQM: 3158-9.

Galambosi, B., Z.S. Galambosi, R. Pessala, I.Hupila, A. Aflatuni, P.K. Svoboda, M. Repcak, 2002. Yield and quality of selected herb cultivars in Finland. Acta Hort. 576: 139149.

Haraguchi, H., T. Saito, H. Ishikawa, H. Date, S. Kataoka, Y. Tamura, K. Mizutani. 1996. Antiperoxidative components in Thymus vulgaris. Planta Med. (62): $217-221$.

Horváth, G., L.G. Szabó, É. Héthelyi, É. Lemberkovics. 2006. Essential oil composition of three cultivated Thymus chemotypes from Hungary. J. Ess. Oil Res, 18(3): 315-317.

Hudaib, M., E. Speroni, A.M. Di Pietra, V. Cavrini. 2002. GC/MS evaluation of thyme (Thymus vulgaris L.) oil composition and variations during the vegetative cycle. J. Pharm. Biom. Annl. 29(4): 691-700. 
Joulain, D., W.A. König. 1998. The Atlas of Spectral Data of Sesquiterpene Hydrocarbons. E.B. Verlag, Hamburg.

Kołodziej, B. 2009. The effect of plantation establishment method and foliar fertilization on the yields and quality of thyme. Annales UMCS, Sec. E, 64(2): 1-7.

Król, B. 2009. The effect of foliar fertilization with Tytanit and Ekolist in thyme culture. Annales UMCS, Sec. E, 64(1): 1-6.

Letchamo, W., A. Gosselin, J. Hoelzl, R. Marquard. 1999. The selection of Thymus vulgaris cultivars to grow in Canada. J. Ess. Oils Res. 11(3): 337-342.

Maghdi, B.H., Z.M. Maki. 2003. Review of common Thyme. J .Med. Plan. 2(7): 1-12.

Marzec M., C. Polakowski, R. Chilczuk, B. Kolodziej. 2010 Evaluation of essential oil content, its chemical composition and price of thyme (Thymus vulgaris L.) raw material available in Poland. Herb Pol., 56(3): 37-52.

Mewes, S., H. Krüger, F. Pank. 2008. Physiological, morphological, chemical and genomic diversities of different origins of thyme (Thymus vulgaris L.). Gen. Res. Crop Evol. 55.8: $1303-1311$

NIST. 2002. Mass Spectral Library. NIST/EPA/NIH, Gaithersburg, MD, USA.

Ozguven, M., S. Tansi. 1998. Drug yield and essential oil of Thymus vulgaris L. as in influenced by ecological and ontogenetical variation. Tur. J. Agric. Forest. 22: 537-542.

Raal, A., E. Arak, A. Orav. 2005. Comparative chemical composition of the essential oil of Thymus vulgaris L. from different geographical sources. Herba Pol. 1/2: 10-17

Rey, C. 1991. The effect of date and height of cut in the first year on the yield of sage and thyme. Revue Suisse de Viticulture. Arboric. Hortic. 23: 137-143.
Sacchetti, G., S. Maietti, M. Muzzoli, M. Scaglianti, S. Manfredini, M. Radice, R. Bruni. 2005. Comparative evaluation of 11 essential oils of different origin as functional antioxidants, antiradicals and antimicrobials in foods. Food Chem. 91(4): 621-632.

Seidler-Łożykowska, K., 2007. The effect of weather conditions on essentials oil content in thyme (Thymus vulgaris L.) and marjoram (Origanum majorana L.). Roczn AR Pozn., Ogrodn 383(41): 605-608.

Senatore, F. 1996. Influence of harvesting time on yield and composition of the essential oil of a thyme (Thymus pulegioides L.) growing wild in Campania (Southern Italy). J. Agric. Food Chem. 44: 1327-32.

Sharafzadeh, S., M. Khosh-Khui, K. Javidnia, O. Alizadeh, K. Ordookhani. 2010. Identification and comparison of essential oil components in leaf and stem of garden Thyme grown under greenhouse conditions. Adv. Environ. Biol. 4(3): 520523.

Skowera, B., J. Puła. 2004. Pluviometric extreme conditionsin spring season in Poland in the years 1971-2000. Acta Agroph. 3, (1): 171- 178.

Stahl-Biskup, E., F. Sáez. 2002. Thyme: the genus Thymus.London: Taylor \& Francis.

Thompson, J. D., J. C. Chalchat, A. Michet, Y. B. Linhart, B. Ehlers. 2003. Qualitative and quantitative variation in monoterpene co-occurrence and composition in the essential oil of Thymus vulgaris chemotypes. J. Chem. Ecol., 29(4): 859-880.

Zawiślak, G. 2007. Analysis of chemical composition of essential oil in the herb of thyme (Thymus vulgaris L.) grown in South-Eastern Poland. Herba Pol., 53(3): 241-244. 